\title{
$\begin{array}{lllllllll}\mathrm{I} & \mathrm{N} & \mathrm{S} & \mathrm{T} & \mathrm{I} & \mathrm{T} & \mathrm{U} & \mathrm{T} & \mathrm{E}\end{array}$
}

\section{More Than One in Ten American Households Relies on Supplemental Nutrition Assistance Program Benefits}

\author{
JESSICA A. BEAN AND MARYBETH J. MATTINGLY
}

$\mathrm{T}$

The Supplemental Nutrition Assistance Program (SNAP) is one of the most critical income supports for vulnerable families nationwide. Each month, SNAP (formerly known as food stamps) helps ensure access to nutritious foods for more than 40 million people, 49 percent of whom are children. ${ }^{1}$ Although any person who meets income requirements is eligible to apply, use of SNAP is unevenly distributed throughout the population. The sharp increase in SNAP use since the recession began in 2007 has considerably widened these gaps in use between groups and places. Using data from the 2007 and 2009 American Community Survey (ACS), we examine differences in SNAP use by region, place type, poverty status, family structure, and race-ethnicity. We also describe changes in use since the onset of the recession.

Nationwide, about one in ten households receives SNAP benefits, an increase of 33 percent since before the recession began in 2007 (see Figure 1). In 2009, SNAP use was lowest in the West, with less than 8 percent of residents reporting assistance, and highest in the South, at 11.4 percent. Rural households are most likely to rely on SNAP, regardless of region, with 13.2 percent of rural households receiving benefits in 2009 compared with 12.7 percent in central cities and 7.7 percent in suburban areas. Among all rural areas, SNAP use is highest in the South, with 15.8 percent of households reporting benefit receipt. This high rate of assistance mirrors 2009 trends in child poverty; the rural South also has the highest rate of child and young child poverty, with one-third of children under age 6 living below the poverty line. ${ }^{2}$

Lone-parent families have particularly high rates of SNAP receipt, with nearly two in five single-mother households, and more than one in five single-father households,

\section{Key Findings}

- Nationally, more than one in ten households relies on SNAP benefits, and the rate is even higher in rural areas, with more than 13 percent of households reporting use.

- Across rural and suburban areas and central cities, the number of households using SNAP has increased since the beginning of the recession in 2007.

- Single-parent households are more likely to rely on SNAP than are households with married parents.

- Use is higher among single-mother households than single-father households; this gap is particularly wide in rural areas.

- In rural areas, SNAP use is highest among black households (30.8 percent), compared with 21.4 percent among rural Hispanic households, and 11.3 percent among rural white households.

- Despite higher use in rural areas, fewer than half of rural households (46.5 percent) with incomes below the poverty line are enrolled in SNAP. Use is even lower in poor central city and suburban households (42.4 percent and 37.8 percent, respectively). 
FIGURE 1: SNAP RECEIPT BY PLACE TYPE ${ }^{1}$

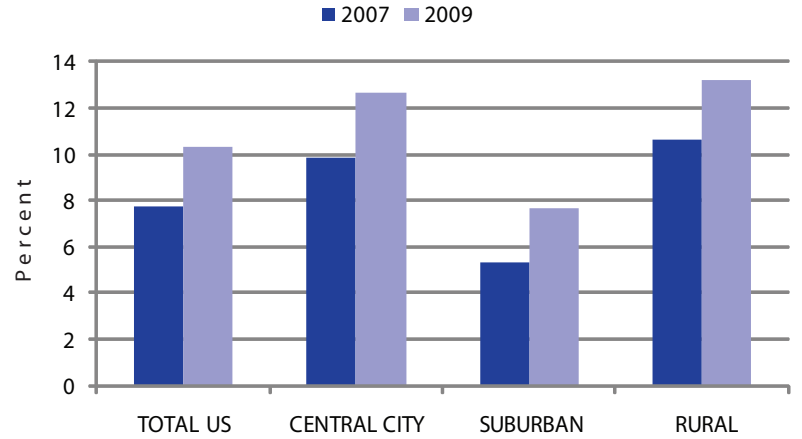

1. All place differences are statistically significant at the $p<0.05$ level.

reporting SNAP use. This compares with fewer than one in ten married couples with children (see Table 1). For all family types, SNAP use has significantly increased since 2007, but particularly so for single fathers, despite higher overall use among single mothers at both times. These trends align with poverty trends as the highest rates of poverty are also among lone parents and in particular among single mothers. ${ }^{3}$ These high rates of SNAP use are not tied to employment, as 71.8 percent of single-mother SNAP recipients nationwide reported living in a household with at least one working adult. Instead, this disproportionate reliance on SNAP by single mothers may be related to the lower earnings of women, and to the fact that women typically bear the most responsibility for the care of children. ${ }^{4}$
SNAP use is particularly high among households with a non-white householder, with nearly one-quarter of black households (23.7 percent) and 17 percent of Hispanic households reporting SNAP benefits. This compares with only 7.9 percent of white households. The racial-ethnic trends in SNAP receipt persist across all regions and all places (see Table 2). These racial-ethnic trends are evident in the 2007 data as well, and appear to have accelerated with the recession; SNAP use among nonwhite households grew at about twice the rate of use among white households between 2007 and 2009.

As with lone-parent households, use of SNAP among nonwhite households mirrors overall poverty trends; nonwhite poverty is disproportionately higher than white poverty, particularly in rural areas. ${ }^{5}$ Correspondingly, SNAP receipt is highest in rural areas, particularly among nonwhites, with 30.8 percent of black rural households and 21.4 percent of Hispanic rural households relying on SNAP (compared to 11.3 percent of rural white households). For whites and Hispanics, SNAP use is higher in the rural South than any other rural region; for blacks, use in the rural Midwest is equally high (more than 30 percent in each case).

Although SNAP provides necessary support for millions of households, there are many more people who might benefit from assistance who are not yet enrolled. To be eligible for SNAP, households must have a gross monthly income equal to or below 130 percent of the federal poverty line (130 percent is currently $\$ 2,389$ per month for a family of four). ${ }^{6}$ Although the eligibility guidelines allow for those

Table 1: Percent Receiving Food Stamps

\begin{tabular}{|c|c|c|c|c|c|c|c|c|c|c|c|c|}
\hline & \multicolumn{3}{|c|}{ ALL PLACE TYPES } & \multicolumn{3}{|c|}{ CENTRAL CITY } & \multicolumn{3}{|c|}{ SUBURBAN } & \multicolumn{3}{|c|}{ RURAL } \\
\hline MARRIED COUPLES & $\begin{array}{l}\text { Estimated } \\
\text { Percentage }\end{array}$ & $\begin{array}{l}\text { Margin } \\
\text { of Error }\end{array}$ & $\begin{array}{c}\text { Change }^{1} \\
\text { Since } 2007\end{array}$ & $\begin{array}{l}\text { Estimated } \\
\text { Percentage }\end{array}$ & $\begin{array}{l}\text { Margin } \\
\text { of Error }\end{array}$ & $\begin{array}{c}\text { Change }^{1} \\
\text { Since } 2007\end{array}$ & $\begin{array}{c}\text { Estimated } \\
\text { Percentage }\end{array}$ & $\begin{array}{l}\text { Margin } \\
\text { of Error }\end{array}$ & $\begin{array}{c}\text { Change }^{1} \\
\text { Since } 2007\end{array}$ & $\begin{array}{l}\text { Estimated } \\
\text { Percentage }\end{array}$ & $\begin{array}{l}\text { Margin } \\
\text { of Error }\end{array}$ & $\begin{array}{c}\text { Change }^{1} \\
\text { Since } 2007\end{array}$ \\
\hline US & 8.9 & $+/-0.11$ & $3.0^{*}$ & 10.7 & $+/-0.23$ & $3.3^{*}$ & 6.9 & $+/-0.15$ & $2.7^{*}$ & 12.9 & $+/-0.35$ & $3.3^{*}$ \\
\hline NORTHEAST & 6.4 & $+/-0.26$ & $2.0^{*}$ & 12.3 & $+/-0.72$ & $3.6^{*}$ & 3.9 & $+/-0.26$ & $1.4^{*}$ & 9.4 & $+/-0.82$ & $2.1^{*}$ \\
\hline MIDWEST & 8.8 & $+/-0.24$ & $2.9^{*}$ & 12.2 & $+/-0.53$ & $3.7^{*}$ & 6.5 & $+/-0.26$ & $2.6^{*}$ & 11.1 & $+/-0.50$ & $3.0^{*}$ \\
\hline SOUTH & 10.5 & $+/-0.20$ & $3.2^{*}$ & 11.0 & $+/-0.43$ & $3.1^{*}$ & 8.6 & $+/-0.21$ & $3.2^{*}$ & 15.4 & $+/-0.56$ & $3.6^{*}$ \\
\hline WEST & 8.6 & $+/-0.25$ & $3.3^{*}$ & 9.0 & $+/-0.39$ & $3.2^{*}$ & 7.6 & $+/-0.33$ & $3.2^{*}$ & 12.0 & $+/-0.82$ & $3.8^{*}$ \\
\hline \multicolumn{13}{|l|}{ SINGLE FATHERS } \\
\hline US & 22.0 & $+/-0.43$ & $7.0^{*}$ & 24.3 & $+/-0.94$ & $7.1^{*}$ & 18.2 & $+/-0.75$ & $6.5^{*}$ & 27.6 & $+/-1.17$ & $7.6^{*}$ \\
\hline NORTHEAST & 20.5 & $+/-1.27$ & $6.0^{*}$ & 28.1 & $+/-2.38$ & $8.1^{*}$ & 14.7 & $+/-1.60$ & $4.2^{*}$ & 25.4 & $+/-3.45$ & $8.1^{*}$ \\
\hline MIDWEST & 24.2 & $+/-0.99$ & $6.9^{*}$ & 29.0 & $+/-1.90$ & $7.0^{*}$ & 19.5 & $+/-1.47$ & $7.2^{*}$ & 26.8 & $+/-1.97$ & $6.1^{*}$ \\
\hline SOUTH & 23.2 & $+/-0.90$ & $7.3^{*}$ & 23.1 & $+/-1.79$ & $5.5^{*}$ & 20.4 & $+/-1.46$ & $7.6^{*}$ & 29.8 & $+/-1.79$ & $8.6^{*}$ \\
\hline WEST & 19.2 & $+/-0.81$ & $7.3^{*}$ & 20.9 & $+/-1.53$ & $8.7^{*}$ & 16.5 & $+/-1.18$ & $6.1^{*}$ & 24.7 & $+/-3.08$ & $7.4^{*}$ \\
\hline \multicolumn{13}{|l|}{ SINGLE MOTHERS } \\
\hline US & 38.4 & $+/-0.29$ & $6.5^{*}$ & 43.2 & $+/-0.53$ & $6.9^{*}$ & 30.8 & $+/-0.4$ & $6.5^{*}$ & 46.9 & $+/-0.76$ & $4.9^{*}$ \\
\hline NORTHEAST & 36.3 & $+/-0.62$ & $6.1^{*}$ & 46.9 & $+/-1.04$ & $7.5^{*}$ & 26.5 & $+/-0.85$ & $6.0^{*}$ & 37.9 & $+/-2.02$ & 1.2 \\
\hline MIDWEST & 43.1 & $+/-0.64$ & $6.9^{*}$ & 50.8 & $+/-1.04$ & $7.3^{*}$ & 34.4 & $+/-0.92$ & $6.9^{*}$ & 45.1 & $+/-1.23$ & $5.2^{*}$ \\
\hline SOUTH & 40.4 & $+/-0.53$ & $6.8^{*}$ & 43.8 & $+/-0.67$ & $6.9^{*}$ & 32.7 & $+/-0.81$ & $7.2^{*}$ & 50.6 & $+/-1.11$ & $5.2^{*}$ \\
\hline WEST & 31.1 & $+/-0.73$ & $5.5^{*}$ & 32.1 & $+/-1.08$ & $5.6^{*}$ & 27.8 & $+/-1.02$ & $5.5^{*}$ & 41.4 & $+/-2.39$ & 5.0 \\
\hline
\end{tabular}

${ }^{1}$ The change since 2007 is a percentage point change.

Note: An asterisk indicates a significant increase since $2007(p<0.05)$. 
Table 2: Percent Receiving Food Stamps

\begin{tabular}{|c|c|c|c|c|c|c|c|c|c|c|c|c|}
\hline & \multicolumn{3}{|c|}{ ALL PLACE TYPES } & \multicolumn{3}{|c|}{ CENTRAL CITY } & \multicolumn{3}{|c|}{ SUBURBAN } & \multicolumn{3}{|c|}{ RURAL } \\
\hline WHITE & $\begin{array}{l}\text { Estimated } \\
\text { Percentage }\end{array}$ & $\begin{array}{l}\text { Margin } \\
\text { of Error }\end{array}$ & $\begin{array}{c}\text { Change }^{1} \\
\text { Since } 2007\end{array}$ & $\begin{array}{l}\text { Estimated } \\
\text { Percentage }\end{array}$ & $\begin{array}{l}\text { Margin } \\
\text { of Error }\end{array}$ & $\begin{array}{c}\text { Change' }^{1} \\
\text { Since } 2007\end{array}$ & $\begin{array}{l}\text { Estimated } \\
\text { Percentage }\end{array}$ & $\begin{array}{l}\text { Margin } \\
\text { of Error }\end{array}$ & $\begin{array}{c}\text { Change' }^{1} \\
\text { Since } 2007\end{array}$ & $\begin{array}{l}\text { Estimated } \\
\text { Percentage }\end{array}$ & $\begin{array}{l}\text { Margin } \\
\text { of Error }\end{array}$ & $\begin{array}{c}\text { Change }^{1} \\
\text { Since } 2007\end{array}$ \\
\hline US & 7.9 & $+/-0.05$ & $2.2^{*}$ & 8.5 & $+/-0.10$ & $2.3^{*}$ & 6.4 & $+/-0.07$ & $2.1^{*}$ & 11.3 & $+/-0.14$ & $2.4^{*}$ \\
\hline NORTHEAST & 7.2 & $+/-0.11$ & $1.8^{*}$ & 11.2 & $+/-0.27$ & $2.4^{*}$ & 5.1 & $+/-0.13$ & $1.5^{*}$ & 10.7 & $+/-0.37$ & $1.9^{*}$ \\
\hline MIDWEST & 8.4 & $+/-0.11$ & $2.2^{*}$ & 9.6 & $+/-0.27$ & $2.2^{*}$ & 6.6 & $+/-0.16$ & $2.1^{*}$ & 10.6 & $+/-0.20$ & $2.3^{*}$ \\
\hline SOUTH & 8.6 & $+/-0.08$ & $2.4^{*}$ & 7.9 & $+/-0.17$ & $2.2^{*}$ & 7.2 & $+/-0.11$ & $2.4^{*}$ & 12.6 & $+/-0.23$ & $2.7^{*}$ \\
\hline WEST & 7.0 & $+/-0.11$ & $2.3^{*}$ & 7.1 & $+/-0.18$ & $2.3^{*}$ & 6.2 & $+/-0.17$ & $2.3^{*}$ & 9.7 & $+/-0.17$ & $2.4^{*}$ \\
\hline \multicolumn{13}{|l|}{ BLACK } \\
\hline US & 23.7 & $+/-0.20$ & $5.0^{*}$ & 26.4 & $+/-0.26$ & $5.5^{*}$ & 17.6 & $+/-0.34$ & $4.4^{*}$ & 30.8 & $+/-0.79$ & $4.0^{*}$ \\
\hline NORTHEAST & 22.1 & $+/-0.53$ & $5.0^{*}$ & 25.4 & $+/-0.61$ & $5.6^{*}$ & 15.6 & $+/-0.97$ & $4.0^{*}$ & 22.5 & $+/-5.87$ & -2.3 \\
\hline MIDWEST & 30.9 & $+/-0.54$ & $6.0^{*}$ & 34.0 & $+/-0.67$ & $6.5^{*}$ & 23.3 & $+/-0.96$ & $4.7^{*}$ & 33.7 & $+/-3.44$ & 4.5 \\
\hline SOUTH & 23.0 & $+/-0.28$ & $4.7^{*}$ & 24.8 & $+/-0.41$ & $5.0^{*}$ & 17.4 & $+/-0.45$ & $4.5^{*}$ & 31.0 & $+/-0.81$ & $4.1^{*}$ \\
\hline WEST & 16.0 & $+/-0.60$ & $4.7^{*}$ & 17.7 & $+/-0.80$ & $5.2^{*}$ & 13.4 & $+/-0.90$ & $3.9^{*}$ & 11.2 & $+/-4.05$ & 2.1 \\
\hline \multicolumn{13}{|l|}{ HISPANIC } \\
\hline US & 17.3 & $+/-0.18$ & $4.7^{*}$ & 19.4 & $+/-0.24$ & $4.6^{*}$ & 14.3 & $+/-0.32$ & $4.6^{*}$ & 21.4 & $+/-0.84$ & $4.8^{*}$ \\
\hline NORTHEAST & 26.0 & $+/-0.54$ & $5.7^{*}$ & 33.1 & $+/-0.72$ & $6.9^{*}$ & 15.8 & $+/-0.69$ & $4.3^{*}$ & 19.2 & $+/-3.50$ & 0.7 \\
\hline MIDWEST & 18.3 & $+/-0.65$ & $5.7^{*}$ & 20.5 & $+/-0.88$ & $5.4^{*}$ & 15.4 & $+/-1.18$ & $6.6^{*}$ & 19.4 & $+/-2.00$ & $4.3^{*}$ \\
\hline SOUTH & 17.6 & $+/-0.30$ & $4.5^{*}$ & 18.1 & $+/-0.45$ & $3.9^{*}$ & 15.6 & $+/-0.46$ & $4.8^{*}$ & 24.1 & $+/-1.22$ & $5.8^{*}$ \\
\hline WEST & 13.5 & $+/-0.32$ & $4.2^{*}$ & 13.9 & $+/-0.41$ & $4.2^{*}$ & 12.5 & $+/-0.43$ & $4.2^{*}$ & 18.6 & $+/-1.40$ & $4.1^{*}$ \\
\hline
\end{tabular}

${ }^{1}$ The change since 2007 is a percentage point change.

Note: An asterisk indicates a significant increase since 2007 ( $p<0.05)$.

slightly above the poverty line to apply for benefits, SNAP enrollment is quite low even among households with income below the poverty line (see Table 3). Nationwide, only 41.6 percent of those living below the poverty line reported receiving SNAP benefits in 2009.

A U.S. Department of Agriculture report found that, among those who were eligible but not enrolled, more than 70 percent cited not knowing they were eligible as a reason for nonparticipation. Other reasons for not applying included the belief that their household did not need food stamps, and disliking the idea of relying on the government for help. ${ }^{7}$ Perhaps owing to growing need brought on by the recession, or increased media attention on federal assistance during the recession, the percentage of poor households receiving
SNAP benefits has increased by 5 percentage points since 2007 (up from 36.6 percent). Use among the poor is particularly low in suburban areas (37.8 percent), and slightly higher in rural areas (46.5 percent). SNAP use among the poor also varies regionally, with less than one-third of poor Westerners (32.4 percent), and nearly one-half of poor Midwestern and Northeastern residents (45.6 and 45.4 percent, respectively) reporting using SNAP.

SNAP is one of the most responsive federal programs to economic downturns, as evidence by the increases in SNAP use between 2007 and 2009. With an average monthly benefit per household of $\$ 275.52$, SNAP can significantly increase a household's purchasing power. ${ }^{8}$ Benefits are usually redeemed quickly, with 80 percent spent within two weeks

Table 3: Percent Below Poverty Line Receiving Food Stamps

\begin{tabular}{|c|c|c|c|c|c|c|c|c|c|c|c|c|}
\hline & \multicolumn{3}{|c|}{ ALL PLACE TYPES } & \multicolumn{3}{|c|}{ CENTRAL CITY } & \multicolumn{3}{|c|}{ SUBURBAN } & \multicolumn{3}{|c|}{ RURAL } \\
\hline & Estimated & Margin & Change $^{1}$ & Estimated & Margin & Change $^{1}$ & Estimated & Margin & Change $^{1}$ & Estimated & Margin & Change $^{1}$ \\
\hline US & 41.6 & $+/-0.23$ & $5.0^{*}$ & 42.4 & $+/-0.32$ & $4.4^{*}$ & 37.8 & $+/-0.38$ & $6.0^{*}$ & 46.5 & $+/-0.55$ & $4.9^{*}$ \\
\hline NORTHEAST & 45.4 & $+/-0.54$ & $5.4^{*}$ & 51.8 & $+/-0.84$ & $4.6^{*}$ & 37.5 & $+/-1.00$ & $6.1^{*}$ & 46.2 & $+/-1.39$ & $4.0^{*}$ \\
\hline MIDWEST & 45.6 & $+/-0.43$ & $4.8^{*}$ & 48.6 & $+/-0.81$ & $4.1^{*}$ & 42.0 & $+/-0.78$ & $5.0^{*}$ & 45.1 & $+/-0.80$ & $4.7^{*}$ \\
\hline SOUTH & 42.4 & $+/-0.45$ & $5.0^{*}$ & 41.2 & $+/-0.63$ & $3.8^{*}$ & 38.9 & $+/-0.57$ & $6.3^{*}$ & 48.6 & $+/-0.83$ & $5.0^{*}$ \\
\hline WEST & 32.4 & $+/-0.45$ & $5.0^{*}$ & 31.0 & $+/-0.64$ & $4.7^{*}$ & 31.7 & $+/-0.84$ & $5.5^{*}$ & 40.4 & $+/-1.00$ & $5.2^{*}$ \\
\hline
\end{tabular}

${ }^{1}$ The change since 2007 is a percentage point change.

Note: An asterisk indicates a significant increase since 2007 ( $p<0.05)$. 


\section{CARSEY INSTITUTE}

of receipt, and 97 percent spent within a month. ${ }^{9}$ In addition to quick turnaround, SNAP benefits spur economic activity, with every $\$ 5.00$ in SNAP generating an estimated $\$ 9.20$ in "total community spending." 10

The 2009 American Recovery and Reinvestment Act (ARRA) increased SNAP benefits beginning in April 2009 , and during the recent recession, SNAP participation increased nationwide. ${ }^{11}$ This increase in participation is likely due to the combination of expanded eligibility under ARRA and increased need due to the recession. ${ }^{12}$ Despite this increased reliance on SNAP, Congress voted in early December to end the ARRA expanded eligibility before the 2014 expiration in order to fund an increase in spending on child nutrition programs. Given that 48 percent of those receiving SNAP are children, ${ }^{13}$ and all children living in households that receive SNAP are likely eligible for free lunch, after-school meals, and summer food programs, the children who benefit from improved child nutrition programs may be the same children who are negatively affected by cuts to SNAP benefits. ${ }^{14}$

\section{Data}

This analysis is based upon U.S. Census Bureau estimates from the 2007 and 2009 American Community Survey released by the U.S. Census Bureau. ${ }^{15}$ Tables were produced by aggregating information from detailed tables available on American FactFinder (http://factfinder.census.gov/home/ saff/main.html?_lang=en). These estimates are meant to give perspective on SNAP use, but because they are based on survey data, use caution in comparing across categories, as the margin of error may place seemingly disparate numbers within sampling error. ${ }^{16}$ All differences highlighted in this brief are statistically significant at the 5 percent level $(p \leq 0.05)$. 


\section{E N D N O T E S}

1. See USDA Food and Nutrition Service, Supplemental Nutrition Assistance Program, "Frequently Asked Questions" (Washington, DC: U.S. Department of Agriculture, n.d.), at http://www.fns.usda.gov/snap/faqs.htm.

2. Marybeth J. Mattingly and Michelle L. Stransky, "Young Child Poverty in 2009: Rural Poverty Rate Jumps to Nearly 29 Percent in Second Year of Recession," Issue Brief No. 17 (Durham, NH: Carsey Institute, University of New Hampshire, 2010).

3. Carsey Institute analysis of 2009 American Community Survey data; not shown.

4. Kristin Smith, "Wives as Breadwinners: Wives' Share of Family Earnings Hits Historic High during the Second Year of the Great Recession," Fact Sheet No. 20 (Durham, NH: Carsey Institute, University of New Hampshire, 2010); Laura T. Kessler, "The Attachment Gap: Employment Discrimination Law, Women's Cultural Caregiving, and the Limits of Economic Liberal Legal Theory," University of Michigan Journal of Law Reform, vol. 371 (2001): 378-380.

5. Kessler, "The Attachment Gap."

6. USDA Food and Nutrition Service, "Frequently Asked Questions."

7. Michael Ponza et al., "Customer Service in the Food Stamp Program: Final Report" (Princeton, NJ: Mathematica Policy Research, 1999), available at www.fns.usda.gov/ora/ menu/published/SNAP/FILES/ProgramOperations/fspcust. pdf.

8. USDA Food and Nutrition Service, "Supplemental Nutrition Assistance Program: Average Monthly Benefit per Household" (Washington, DC: U.S. Department of Agriculture, 2010), available at www.fns.usda.gov/ pd/19SNAPavg\$HH.htm.

9. Center on Budget and Policy Priorities, "Introduction to the Food Stamp Program" (Washington, DC: CBPP, 2010); USDA Food and Nutrition Service, "The Stimulus Package and SNAP: How the American Recovery and Reinvestment Act Affects SNAP Benefits and Policies" (Washington, DC: U.S. Department of Agriculture, 2009).

10. USDA Food and Nutrition Service, "The Stimulus Package and SNAP."

11. See also Center on Budget and Policy Priorities, "Introduction to the Food Stamp Program."

12. USDA Food and Nutrition Services, Supplemental Nutrition Assistance Program, "American Recovery and Reinvestment Act Plan Update" (Washington, DC: U.S. Department of Agriculture, 2010).

13. USDA Food and Nutrition Service, "Characteristics of Supplemental Nutrition Assistance Program Households: Fiscal Year 2009 Summary" (Washington, DC: U.S. Depart- ment of Agriculture, 2010), available at http://www.fns.usda. gov/ora/menu/Published/snap/FILES/Participation/2009Ch aracteristicsSummary.pdf.

14. Zoë Neuberger, "USDA Study Shows States Failing to Connect Many Needy Children to Free School Meals" (Washington, DC: Center on Budget and Policy Priorities, 2009).

15. See American Fact Finder, available at http://factfinder.census.gov/servlet/DTGeoSearchByListServlet?ds_ name $=$ ACS_2009_1YR_G00_\&_lang $=$ en\&_ $\mathrm{ts}=306335491183$.

16. Refer to the Census Bureau's published tables for detailed margins of error.

\section{ABOUT THE AUTHORS}

Jess Bean is a vulnerable families research associate at the Carsey Institute. (jessica.bean@unh.edu)

Beth Mattingly is director of research on vulnerable families at the Carsey Institute and research assistant professor of sociology at the University of New Hampshire. (beth.mattingly@unh.edu)

\section{A C K N O W L E D G M E N T S}

The authors thank Mil Duncan, Curt Grimm, Terri Rippett, Laurel Lloyd Earnshaw, Amy Sterndale, Kristin Smith, Barbara Wauchope, and Andrew Schaefer at the Carsey Institute; Debbie Stein at the Hatcher Group; and Barbara Ray at Hiredpen for comments and suggestions. 


\section{$\triangle$ UNIVERSITY m. of NEW HAMPSHIRE}

\section{CARSEY}

Building knowledge for families and communities

The Carsey Institute conducts policy research on vulnerable children, youth, and families and on sustainable community development. We give policy makers and practitioners timely, independent resources to effect change in their communities.

This work was supported by the Annie E. Casey Foundation, the W. K. Kellogg Foundation, and an anonymous donor.

Huddleston Hall

73 Main Street

Durham, NH 03824

(603) $862-2821$

www.carseyinstitute.unh.edu 